\title{
Do not bank on us! Taking stock of transparency and accountability during crises in Uganda: the case of Crane Bank collapse
}

\author{
Angella Napakol \\ Uganda Christian University \\ Mukono, Uganda \\ Ann Mugunga \\ Hong Kong Baptist University \\ Hong Kong
}

\begin{abstract}
This study examined transparency and accountability as bridges to the interpretative and sense making capabilities of the public following the collapse of Crane Bank, Uganda. Content and critical discourse analysis methods were used to: investigate the nature of communication, the information shared; review honesty and responsibility in communication, and also analyze how accountability and transparency are constructed during crisis situations in the South. Assessment of 120 newspaper articles showed that both Crane Bank and Bank of Uganda mainly left it to the media to create and give meaning to stakeholders. Initial communication from both institutions was delayed and subsequent communication was made in a casual, vague and dismissive manner. Transparency and accountability either as information disclosure, responsibility or mutual understanding to translate into sense making for the audience were grossly undermined. Most of the shared information was not aligned to the interpretive capabilities of audiences; and there was no effort to create a good image or influence the audience. The research underscores the importance of transparency and accountability as essential for creating trust in leadership and management, in order to better manage crisis and risk situations.
\end{abstract}

Keywords - Accountability, crisis, sense making, sense giving, transparency

SUGGESTED CITATION: Napakol, A., \& Mugunga, A. (2019). Do not bank on us! Taking stock of transparency and accountability during crises in Uganda: the case of Crane Bank collapse. Proceedings of the International Crisis and Risk Communication Conference, Volume 2 (pp. 23-26). Orlando Fl: Nicholson School of Communication and Media. https://doi.org/10.30658/icrcc.2019.7

\section{INTRODUCTION}

Transparency and accountability are key issues in contemporary strategic communication. Corporations acquire legitimacy by way of communicative practices. During crises, transparency and accountability are "pervasive ideals that are increasingly demanded by inquisitive stakeholders" p.1 [1]. Critical stakeholders are now more than ever challenging transparency and accountability during organizational crises, putting organizations in complex situations of having to grapple with the ideal of transparency. In Uganda, however, issues of accountability and transparency are treated casually by organizations despite increasing demand for the same by stakeholders.

Although capacious amount of research on transparency and accountability has materialized in the recent years $[1,2$, 3], this paper wishes to add a global south perspective. The article examines the practice of information giving as a source of transparency and accountability. Using the frameworks of sense-giving and sense-making [1], transparency and accountability in this study includes the amount of information shared, the content of the message, who communicated, who was consulted, what explanation, if any, was given and general sense of ownership by the organization. Although the crisis under study is the collapse of Crane Bank, Bank of Uganda (also known as the Central Bank) is included in this study

ISSN: 2576-9111

(C) 2019 Copyright is held by the owner/author(s).

Publication rights are licensed to ICRCC.

https://doi.org/10.30658/icrcc.2019.7 
because of the improbability surrounding the collapse of Crane Bank. The bank also holds a central role as overseer and regulator of Uganda's banking sector and should, therefore, be accountable to the people of Uganda.

\section{LITERAURE REVIEW}

Transparency and accountability in corporate communication has been largely associated with information giving [4] information sharing [5] and honest communication [6]. According to Albu and Wehmeier [1], such definitions and associations of the concept of transparency are simplistic. These authors hold that transparency in corporate communication should go beyond simply honest communication, information sharing and giving, to facilitate sense making and interpretive capabilities of stakeholders. The scholars add their voice to Christensen [7] who noted that the study of transparency in corporate communication is devoid of theory and reflective arguments and emphasized the damaging and inadvertent effects of 'information sharing' type of transparency. These authors argue that the prerequisites of transparency are inclined to create "information without reception, and openness without trust, because they are not bound to the interpretive and sense-making capabilities of the publics" p.118 [1].

Most official information, including the one that is disseminated to ensure accountability and/or transparency is incomprehensible to envisioned audiences and most of it is encumbered with irrelevances that the audiences cannot tell which bits are of importance [8]. This type of transparency is often referred to as nominal transparency to mean "transparency that is ritualized and decoupled from the process of communication and may in contrast to professed intentions, produce confusion, prejudice and misleading beliefs" p. 119 [1]. It is a polished type of communication that relies on information disclosure and often clogged with the notion that communication and content generation is controlled by the affected organization $[1,8]$.

The argument that communication and content creation are not controlled by a single source makes it imperative for leaders of organizations in crisis to take control of situations and offer explanations and solutions. Crisis situations can breed speculation, fear and an array of emotions and reactions which when not mediated by the authorities in charge can get out of hand. The public "expects leaders to avert the threat or at least minimize the damage of the crisis at hand. They must explain what went wrong. They must adapt, change, abandon routine ways of operating where needed and create public confidence in the new status quo" p.78 [9]. Crises provide real-world "stress tests" to the resilience of political systems and the crisis management capacities of leaders. They play out against a backdrop of public expectations that can be very challenging to meet. This underlines the importance of effective crisis communication and management before, during and after the crisis [1]. A well organized and effectively communicated response and recovery helps to repair - or even enhance - public trust in the leadership and the functioning of social institutions - and the aftermath of a crisis marked by proper accountability procedures and a willingness to collectively learn the lessons of that crisis. Responsibility requires accountability and the organization must answer for its actions.

The explanations and or solutions offered by leaders help in the meaning making process. The organization narrative is aided by the message, action, interpretation and perception, all of which are elements of the sense-giving and sense-making framework; which is a process-oriented practice of creating and construction meaning. Sense giving "attempts to influence the sense-making and meaning construction of others...sense making involves a retrospective development of plausible images that rationalize what people are doing" p.275 [10]. During crises, organizations have to react without having time to think strategically; they are forced to be swift. This means that any organization without crisis communication plans are disadvantaged yet they are under pressure to create a narrative and "offer authoritative definition of the situation, provide hope, show empathy for victims .... and reduce public anxiety" p.80 [1]. However, much as the public expects organizations to manage the meaning making process, they expect that the process is marked with accountability and transparency beyond information sharing.

From the review of literature above, the following research questions were derived:

1. How was transparency and accountability presented in the articles that covered the Crane Bank crisis.

This question looked at the different themes that dominated the discussion, the causes of the Crane Bank collapse, what messages and how the messages were communicated.

2. How did the leaders of both Crane Bank and Bank of Uganda communicate before, during and after the crisis? Leaders help to create a desirable narrative during crises. This question specifically looked at when the leaders communicated, how, and what they said.

3. What were the key sources of information?

The question considered who wrote the stories and who was consulted for the information that was published. All three questions lend themselves to understanding how meaning making was constructed during after the Crane Bank crisis.

\section{METHODS}

This study used quantitative content analysis and critical discourse analysis (CDA) to answer the above research questions. Content analysis was used to understand the nature of coverage for instance amount of coverage, key topics of discussion, who communicated and who was contacted as a source of information about the crisis. A total of $N=120$ articles were collected from both New Vision and Daily Monitor newspapers beginning in April 2016 when the Crane Bank crisis started, 
to December 2017, three months after the bank was put under receivership. New Vision and Daily Monitor are the major English dailies in Uganda.

Discourse analysis was used to lend an interpretive perspective to the study by going in-depth to appreciate the intricacies in communication. The interpretive paradigm highlights the unique position of the audience in a discourse social process. Meso analysis was used to understand the different discursive positions within transparency while attending to detail and complexity in language [1]. A total of 10 (ten) articles were subjected to CDA. These were critical incident stories of, for example, the first article after the rumors about the collapse of the bank started, the first time Crane Bank or Central Bank responded, articles by the CEOs of Crane and Central Bank; articles that highlighted people's plight, or those showing what actions customers were taking up such as withdrawing savings from Crane Bank. The reason for the diverse inclusion was to enable analysis of transparency and accountability as co-constructed by the interplay between stakeholders, Crane Bank and the Central Bank.

\section{RESULTS}

The first question interrogated how transparency and accountability were portrayed during the Crane Bank crisis. A total of $\mathrm{N}=120$ articles for the 21 months period of study met the selection criteria $(n=54$ and $n=66$ New Vision and Daily Monitor respectively). The major themes of discussion in the articles were transparency, attribution of blame, illegal dealings and suspicion ( $n=67, n=61, n=38$ and $n=34$ respectively) while among those infrequently discussed were denial by central bank and the social and economic cost of the crisis $(n=14, n=18$ respectively). Transparency recorded more coverage $(n=67)$ compared to accountability, $n=33$. A follow up critical discourse analysis also showed a dismissive attitude especially towards accountability as will be elaborated later in the text. Among the causes, financial mismanagement $(n=77,22.2 \%)$, fraud $(n=57,16.4 \%)$, gone bad debts and insider lending both $(n=48,13.8 \%)$ and none performing loans $(n=45,13 \%)$ were discussed most.

Question two asked how leaders of both Crane Bank and Central Bank communicated during the crisis. Both institutions delayed to respond. It took Crane Bank three months from the time rumors started circulating to release a statement. After this, there was no other direct communication from Crane Bank CEO other than accounts by two journalists who claimed to have had phone interviews with him after the press release. Critical discourse analysis uncovered a dismissive attitude especially towards accountability; for instance the journalists said the CEO Crane Bank only reiterated what was in the press release and asked them if they had not read it, when asked to explain what was going on in terms of cause and remedy to the bank collapse. As a source, the CEO Crane Bank appeared $n=30$ times while the Governor, Central Bank appeared $n=13$ times. However, CDA analysis shows that the Central Bank Governor responded personally and sought to clarify misrepresentations and was more accountable than the CEO Crane Bank

The final question studied the different sources of information about the Crane Bank crisis. All articles that were studied were written by journalists, apart from press releases by both Crane Bank and Bank of Uganda and three articles by the Governor, Bank of Uganda. Among the most used sources were government officials $(n=67,55.8 \%)$, financial and economic experts $(n=35,29.2 \%)$ while the least consulted were civil society organizations ( $n=12,10 \%)$.

\section{DISSCUSSION}

The communicative narrative during the Crane Bank crisis was left to journalists who framed most of it. Although there was sizeable input from government officials, how an organization crafts a narrative will always be different from the way that journalists do. The stakeholders, for example those saving with the bank need to hear from the institution directly in times of crisis. Both Crane Bank and Central Bank were not proactive in communicating to the stakeholders. Rumors about the collapse of the bank started in April 2016 but Crane Bank only responded in September with a press release emphasizing that the bank was "in good standing and in the market for a strategic partner". However, barely a month after that assurance, Crane Bank was put under receivership by the Bank of Uganda. The delayed response and subsequent untruthful assurances of good standing reflect poor transparency and lack of accountability.

Although the governor, Bank of Uganda tried to communicate personally and offered explanations to stakeholders, he was often dismissive and abrasive. In one of the articles, the governor bank of Uganda played down the closure of Crane Bank and even referred to those who thought so as fools. He said that, "... so for those who claim that the bank has collapsed are fools, the bank is alive and well, if not, kicking" p.1. The language used and the attitude by the governor did not help to create a formidable narrative instead, it showed the disregard that most corporate organizations and or government entities have towards stakeholder opinions and fears during crises. Studies reviewed early in this research showed that organizations in the North struggled with nominal transparency, where information sharing and honesty is mistaken for transparency and or accountability, the results from this study indicate a distinct contrast with the south where neither information sharing and honesty nor transparency or accountability are considered important.

The leadership of both organizations did very little to allay stakeholder fears and speculation. In addition to being abrasive, communication from both was, at best, inconsistent. For example, Crane Bank was already under receivership when the governor emphasized that it was 'alive and well, if not, kicking' and barely two months later, Crane Bank was sold off to DFCU bank. During crises, such inconsistencies only work to heighten tension and uncertainty [1]. For the case 
of Crane Bank, customers responded by withdrawing their savings from the different branches of the bank before they were checked by Central Bank.

\section{CONCLUSION}

A number of studies have been conducted on crisis management and effective communication in the Global North. Our research is one of the few first studies conducted in Uganda in particular, to highlight the importance of transparency and accountability for effective crisis management. This study clearly shows that transparency and accountability either as information disclosure, responsibility or mutual understanding are necessary if stakeholders are to make sense of and manage a crisis situation. The results offer a reference for the prevention of problematic crisis communication. However, since this was a case study, the results also offer an opportunity for future research to investigate other crisis situations in the global South. Further studies should provide a comprehensive case book for crisis and risk communication.

\section{Author Biography}

Angella Napakol: PhD, University of KwaZulu Natal, South Africa, Head of Communication Department, Uganda Christian University. Angella.Napakol@gmail.com

Ann Mugunga: MA, University of Leeds, UK; PhD Student, Hong Kong Baptist University, Hong Kong. Ann.mugunga@gmail.com

\section{REFERENCES}

[1] Albu, O. B. \& Wehmeier, S. (2014). Organizational transparency and sense-making: The case of Northern Rock. Journal of Public Research, 26, 117-133. https://doi.org/10.1080/1062726X.2013.795869

[2] Cheng, S. S. \& Seeger, M. W. (2010) Cultural Differences and Communication Issues in International Mergers and Acquisitions: A Case Study of BenQ Debacle, International Journal of Business and Social Science, 3(3) Accessed at: https://pdfs.semanticscholar.org/

[3] Garsten, C. \& Montoya, L. (2008) Transparency in a new global order: Unveiling organizational visions. Edward Elgar, USA.

[4] Bushman, R., Chen, Q., Engel, E., \& Smith, A. (2004). Financial accounting information, organizational complexity and corporate governance systems. Journal of Accounting and Economics, 37(2), 167-201. https://doi.org/10.1016/j.jacceco.2003.09.005

[5] Yang, S.-U., \& Lim, J. S. (2009). Effects of blog-mediated public relations on relational trust. Journal of Public Relations Research, 21, 341-359. https://doi.org/10.1080/10627260802640773

[6] Rawlins, B. (2009). Give the emperor a mirror: toward developing a stakeholder measurement of organizational transparency. Journal of Public Relations research, 21, 71-99. https://doi.org/10.1080/10627260802153421

[7] Christensen, L. T. \& Langer, R. (2009). Public relations and the strategic use of transparency. Consistency, hypocrisy and cooperate change. In R. L. Heath, E. Toth, \& E. Waymer (Eds), Rhetorical and critical approaches in public relations 11 (pp.129-153). Hillsdale, NY: Routledge

[8] O’Neill, O. (2006). Transparency and the ethics of communication. In C. Hood \& D. Heald (Eds), Transparency; key to a better governance (pp. 75-90). Oxford, UK: Oxford University Press.

[9] Boin, A., Hart P., Stern, E. and Sundelius, B. (2017). The politics of crisis management: public leadership under pressure. Cambridge University Press.

[10] Taylor, J. R \& Van Every, E. J. (2000). The emergent organization: Communication as its site and surface. Mahwah, NJ: Lawrence Erlbaum Associates. 